\title{
O CAPITAL CONTRA A EDUCAÇÃO DA CLASSE TRABALHADORA
}

\author{
EL CAPITAL CONTRA LA EDUCACIÓN EN CLASE DE TRABAJO
}

\section{THE CAPITAL AGAINST WORKING CLASS EDUCATION}

DOI: http://dx.doi.org/10.9771/gmed.v11i1.33557

\author{
Elza Peixoto ${ }^{1}$ \\ Vania Pereira Moraes Lopes ${ }^{2}$ \\ Edson do Espírito Santo Filho ${ }^{3}$ \\ Itamar Silva de Sousa ${ }^{4}$ \\ Grupo de estudos e pesquisas Marxismo e Políticas de Trabalho e Educação - MTE5
}

Contra a propagação de uma retórica farsante acerca de uma unidade de sacrifício patriótico travestida de verde amarelo, um conjunto de reformas evidencia de forma contundente um quadro de acirrada luta de classes no Brasil. O ataque dos que detêm as forças produtivas contra aqueles que só podem manter a vida subordinando-se à legislação trabalhista ${ }^{6}$, ao emprego intermitente e precário ${ }^{7}$, ao assédio moral, ao controle do tempo livre e das formas de distribuição dos meios necessários à vida enquanto riquezas socialmente produzidas - a classe trabalhadora - ocorre de forma direta, via reforma constitucional ${ }^{8}$ que promove retirada de direitos duramente conquistados pelos trabalhadores, seguido de repressão violenta com o auxílio do aparato da força armada do Estado, da polícia, da justiça de classe ${ }^{9}$, das milícias ${ }^{10}$, ou ainda, via difamação dos movimentos dos trabalhadores no tenso controle dos meios de comunicação de massa ${ }^{11}$.

Em especial, a análise ${ }^{12}$ dos documentos oficiais com os quais o Capital coordena a organização da vida social evidenciam a profundidade e a violência do ataque contra os interesses e necessidades dos trabalhadores. A direção da política econômica nestes documentos ${ }^{13}$ emitidos pelos órgãos centrais de gestão do capitalismo mundial, como o Banco Mundial14, revelam os eixos de uma reestruturação das tarefas do Estado ${ }^{15}$ nas relações de produção capitalistas, com vistas a tornar mais agressivo seu direcionamento para o atendimento dos interesses do capital financeiro ${ }^{16}$. Esta reforma impacta especialmente as políticas sociais ${ }^{17}$ e a política nacional de ciência e tecnologia ${ }^{18}$. São a prova de uma ação orquestrada de ataques do capital $^{19}$ contra a classe trabalhadora, que subordinam a vida insignificante ${ }^{20}$ e excedente ${ }^{21}$ dos que produzem a riqueza ${ }^{22}$ - os trabalhadores - à gestão e ao controle da coisa pública conduzida, sob a perspectiva neoliberal23, conforme os interesses do capital financeiro ${ }^{24}$. Um ataque que evidencia o 
desespero ${ }^{25}$ pela preservação da acumulação privada assim como o desprezo ${ }^{26}$ e o sacrifício ${ }^{27}$ da força de trabalho que produz toda a riqueza social ${ }^{28}$.

Embora agrave-se significativamente no governo Bolsonaro, sob uma campanha de violência claramente impetrada com a finalidade de alimentar a indústria bélica estimulando-se a venda de $\operatorname{armamentos}^{29}$ para a população civil - estes ataques, entretanto, não se iniciam com este Governo ${ }^{30}$. Pelo contrário, é este Governo a máxima expressão do grau de ataque que a classe trabalhadora vem sofrendo, especialmente após a queda do Leste, que se concretiza num conjunto de reformas reacionárias que se encontram em processo no Brasil, na América Latina e na Europa, explicitando a avidez por espoliação nas metas estabelecidas pelas frações do capital que concorrem entre si ${ }^{31} \mathrm{em}$ busca dos maiores lucros.

A liberalização da economia e da satisfação das necessidades individuais andava já a passos largos nos últimos 30 anos, e vem sendo intensificada com os governos Temer e Bolsonaro. Especificamente, o ataque à classe trabalhadora brasileira vem se dando (1) na forma da concentração da riqueza ${ }^{32}$; (2) na forma do agravamento da expulsão de trabalhadores do acesso ao trabalho, que, em sua expressão no Brasil, condena à exclusão de cerca de 50 milhões de trabalhadores do acesso regular a salários, único meio que viabiliza a aquisição dos meios de vida nas relações de produção capitalistas ${ }^{33}$; (3) na forma de corte de gastos com as políticas sociais ${ }^{34}$ levando ao profundo abandono e à ausência de alternativas de ocupação remunerada $^{35}$ e subsistência dos setores sem acesso ao trabalho em um quadro no qual 1 em cada 4 brasileiros estão desempregados ${ }^{36}$ ou subempregados; (4) na forma da reforma da legislação trabalhista ${ }^{37}$ que leva à expansão da extração da mais valia sobre a minoria empregada; (5) na forma do prolongamento do tempo de trabalho e negação do direito ao tempo livre e à aposentadoria remunerados via reforma da previdência ${ }^{38}$; (6) na forma do desmonte e estrangulamento da educação pública e gerenciamento dos parcos recursos via fechamento de escolas ${ }^{39}$ e remanejamento e redistribuição dos estudantes pelas escolas disponíveis; (7) no avanço de sua militarização40; (8) na proposição do "ensino domiciliar"41; (9) na condenação da classe trabalhadora desocupada ao encarceramento ${ }^{42}$; (10) no extermínio da juventude pelas polícia e milícias ${ }^{43}$; e, por fim, (11) na forma da reforma das diretrizes curriculares para a educação básica em perspectiva conservadora ${ }^{44}$; (12) na forma do avanço contundente do capital no (i) controle do material didático a circular nas escolas; (ii) contra os referenciais que contribuem para a formação crítica da classe trabalhadora e contra (iii) as forças de esquerda que propagam estes referenciais ${ }^{45}$. Particularmente, este último ataque visa impedir aos trabalhadores o acesso a qualquer vestígio de conhecimento das condições nas quais vivem.

Enfatizamos que compõe este projeto da classe dos capitalistas e de seus serviçais, o impedimento e a tentativa de extermínio de qualquer possibilidade de reorganização dos trabalhadores e de apoio em referências que lhes convidem nesta direção ${ }^{46}$. Nunca é demais recordar que nos últimos anos várias táticas foram utilizadas para associar a imensa massa de desempregados ao fim da centralidade do trabalho na produção do capital ${ }^{47}$. Várias escaramuças têm sido utilizadas para apagar a identidade da classe trabalhadora ${ }^{48}$, apagando a cientificidade da investigação de Marx quanto à centralidade do emprego da mercadoria força de trabalho para o nascimento do Capital como força econômica e modo de produção, 
que coloca esta classe com cadeias radicais ${ }^{49}$ como classe potencialmente revolucionária das relações de produção capitalistas.

É por esta razão que, no processo de negação de acesso aos bens socialmente produzidos, um dos ataques mais perversos e mais contundentes do capital à classe trabalhadora evidencia-se no desmonte da educação pública. A história da educação nos mostra que o acesso à educação se constituiu e se constitui continuamente em uma intensa disputa contra os limites impostos pelos interesses dos capitalistas à educação dos trabalhadores ${ }^{50}$. No Brasil, o processo de negação da educação é extremamente grave, considerando que se trata da nona economia mundial ${ }^{51}$ que detém um dos maiores índices de analfabetismo do mundo 52 ! Por aqui, o processo de ataque à educação da classe trabalhadora começa muito antes de ocorrer o fechamento de escolas. Executa-se com a recusa de destinar recursos à educação pública e tornase contínua com o avanço sucessivo sobre os parcos recursos conquistados com as lutas dos trabalhadores da educação, na forma dos sucessivos cortes de verbas, nunca atingindo àquilo que vem sendo reivindicado pelos trabalhadores. A negação do acesso à educação pública e gratuita, laica, referenciada nos interesses da classe trabalhadora, prossegue pela degradação e pelo desincentivo à carreira do magistério em todos os níveis; pela não substituição das vacâncias por morte, licenças médicas ou de capacitação; pelo rebaixamento dos salários e a não reposição das perdas inflacionárias; pela campanha de desqualificação, difamação e criminalização do professorado com perspectiva crítica via Escola Sem Partido ${ }^{53}$; pelo tratamento das lutas dos professores como questão de polícia de contenção de massas ${ }^{54}$; pela negação do direito às licenças capacitação remuneradas ${ }^{55}$; pelo rebaixamento da formação de professores e negação da ciência e da técnica como eixos da educação básica ${ }^{56}$; pela subordinação da formação ao relativismo ${ }^{57}$ e aos irracionalismos ${ }^{58}$ que culminam com a sobreposição dos misticismos à ciência. Nos governos instalados a partir de 2015, o processo de ataques à educação da classe trabalhadora intensifica-se com o avanço da privatização da educação básica, e a proposição da educação à distância ${ }^{59}$ e domiciliar como alternativa de substituição.

No âmbito do ensino superior, com o FUTURE-SE ${ }^{60}$, evidencia-se sem pudor uma das metas da reforma do Estado e da reforma constitucional em andamento, com uma indecorosa proposta de liquidação do patrimônio das IFES (em termos de instalações e pessoal altamente qualificado) e dos parcos recursos que vinham sendo destinados ao ensino superior público e à ciência e tecnologia no Brasil para a sua conversão em recursos a serem aplicados em fundos financeiros privados atrelados e subordinados à especulação e à volatilidade em que se movimenta o capital financeiro internacional. O Ministério da Educação, via FUTURE-SE, recomenda a centralização da gestão nas Organizações Sociais que desde Fernando Henrique Cardoso ${ }^{61}$ tentam estabelecer-se nos serviços públicos, retirando das Universidades a autonomia de gestão financeira, e colocando-a totalmente subordinada aos interesses do capital financeiro. O parco projeto de uma ciência e tecnologia soberanas, ensaiado precariamente no Brasil desde os anos $50^{62}$ do século XX, é destroçado e jogado à jaula dos vorazes interesses privados. Ao professorado, o convite a empreender e inovar, quem sabe, recebendo percentuais dos rendimentos obtidos com a conversão de todo o patrimônio em capital especulativo ${ }^{63}$ e a certeza do agravamento da intensificação do trabalho ${ }^{64} \mathrm{e}$ do rebaixamento dos salários ${ }^{65}$. Com o definitivo desmonte das agências de fomento à pesquisa, CNPq e CAPES ocorre o comprometimento absoluto do acesso da Classe Trabalhadora à Pós-Graduação. Os sinais 
são claros: experimentaremos ainda mais violento arrocho na produção dos periódicos pelos quais passam a avaliação da produção docente, mercadoria pela qual são trocadas as verbas para o sustento de uma minoria de cursos de pós-graduação.

Os que produzimos Germinal resistimos! Nos somamos a todos aqueles que denunciam que este é um país dividido, polarizado entre os que defendem os interesses dos trabalhadores e os que defendem os interesses e a perspectiva da acumulação privada (muitos deles, membros da classe trabalhadora - a imensa massa de cristãos e pentecostais que elegeram as bestas - deputados, senadores e presidente - vinculados à bancada $\mathrm{BBB}^{66}$, que ocuparam o Planalto Central a fazer arder em brasa e a verter em cinzas os direitos daqueles a quem dizem representar, em um processo que denota a profundidade da vitória ideológica da direita nos últimos 30 anos!!)

Este Volume 11, Número 1 de Germinal expressa o esforço empreendido pelos intelectuais e educadores marxistas de realizar a crítica materialista e dialética desta conjuntura, enfrentando-a com radicalidade, reconhecendo o movimento da correlação de forças e os limites e possibilidades das políticas que foram possíveis no seio do embate entre capital e trabalho em nível mundial. São 28 manuscritos distribuídos nas seções Debates, Artigos, Entrevista, Documento e Resenha que, no conjunto, cumprem o papel de recuperar a lógica dos processos históricos, os agentes e os instrumentos que foram utilizados pelo Capital no processo coordenado de manter-se hegemônico no controle da produção da existência e na concentração de suas vantagens, mesmo quando parecia as dividir.

Na Seção Debates, 09 manuscritos trazem importantes balanços de aspectos da conjuntura e das reformas contra as quais temos ido às ruas, contribuindo para que apreendamos as múltiplas determinações dos processos de ataque à educação da classe trabalhadora em todo o mundo!! Daniel Santos Braga e Túlio César Dias Lopes trazem “A educação sob a lógica do capital: constituição e consolidação das políticas educacionais em países periféricos do capitalismo mundial" "67; Franciel Coelho Luz de Amorim, Maria Jorge dos Santos Leite analisam "A influência do banco mundial na educação brasileira: a definição de um ajuste injusto"68; Aline Soares Nomeriano, Renalvo Cavalcante Silva enviaram "As políticas de austeridade e as atuais reformas do estado brasileiro: respostas dadas à crise capitalista" "69; Mauro Titton e Adriana D'Agostini "Juventude e educação no contexto do desemprego crônico na Espanha e no Brasil"70; Marcelo Lira Silva, debate "A base do golpe: a nova colonização pela captura da subjetividade" " Celi Nelza Zulke Taffarel e José Arlen Beltrão trazem "Destruição de forças produtivas e o rebaixamento da formação da classe trabalhadora: o caso da reforma e da BNCC do ensino médio"72; João Gomes Moreira, Maria Eliza Nogueira Oliveira, Regilson Maciel Borges "Relação público-privada e precarização do trabalho: duas faces da mesma moeda"73; Cleverson Molinari Mello "As modernas competências profissionais como forma de dissimulação da antiga exploração do trabalhador" "; Henrique Tahan Novaes traz "O fim da república brasileira e a urgência da educação para além do capital" ${ }^{75}$. No conjunto, temos nesta seção textos polêmicos, que possibilitam reconhecer os debates acerca do levantamento e da interpretação das múltiplas determinações dos processos que nos trazem a esta conjuntura. Evidencia-se a subordinação dos governos brasileiros desde FHC ao Consenso de Washington, as políticas educacionais daí decorrentes, especialmente conduzidas na forma de condicionalidades cruzadas pelo Banco Mundial para a concessão de empréstimos, o impacto 
desta conjuntura para a classe trabalhadora em geral e suas organizações, e, em especial, para a juventude. Outros manuscritos destacam a conjuntura de crise do capitalismo e destruição das forças produtivas, amenizando, entretanto, as responsabilidades dos governos e dos organismos da classe trabalhadora como parte das determinações das formas concretas como estes processos ocorreram no Brasil. Fechando a seção, temos a indicação da necessidade de um projeto de superação das perspectivas reformistas para além do capital, em um convite à retomada da formação de base empreendida pelos intelectuais durante os processos revolucionários.

Na Seção Artigos, 14 manuscritos enfrentam diferentes aspectos dos problemas educacionais num quadro de crise. Wagner Pires da Silva, Paulo Henrique Freitas Maciel, Ana Carmita Bezerra de Souza, "Educação e trabalho em tempos de precarização"76; Mariléia Maria da Silva "Jovens da EJA na "ilha da magia": condições de trabalho, educação e migração"; Breno Pascal de Lacerda Brito, Victor Montalvão Moreno, Thayse Ancilla Maria de Melo Gomes "Relação escola, educação e a luta de classes e seus papéis na formação do sujeito revolucionário"77; Leonardo Carnut, Tarsila Teixeira Vilhena Lopes, Samara Jamile Mendes, Áquilas Mendes trazem "Passei a entender a influência do capital na saúde pública...”: formação política crítica dos trabalhadores do sistema único de saúde" "78; Marizete Andrade da Silva, Hormindo Pereira de Souza Júnior “A preservação das comunas camponesas russas e a construção do socialismo: análise dos rascunhos de carta de Karl Marx - Vera Zasulitch (1881)"'79; Alessandro Santos Mariano, José Claudinei Lombardi "Método de formação política da escola nacional Florestan Fernandes do MST"80; Nelson Kautzner Marques Junior "Benefícios da Revolução Russa"s1; Amarilio Ferreira Jr. E Mariza Bittar "A concepção materialista da história: divergências entre Thompson e Althusser" "2; Aline Maestre Polido, Fátima Aparecida de Souza Francioli trazem “A modernidade capitalista e o papel da educação" "83; Vanderlei Amboni traz "Trabalho e educação na reprodução social do homem" "4; Iael de Souza "Da filosofia aos fundamentos filosóficos da educação - primeiras aproximações" 55 ; Camila Itikawa Gimenes "A teoria e a prática na formação inicial de professores: algumas definições"86; Osmar Hélio Alves Araújo "Didática e a prática docente na escola básica em uma perspectiva crítica de educação"87; Luiz Bezerra Neto, Juan Carlos Rodriguez Cruz trazem "La posmodernidad y la autenticidad patrimonial en su relación con la cultura campesina y la educación media en cuba y Brasil"»8. No conjunto, os artigos desta seção evidenciam a esperança e a luta pela abertura de possibilidades de intervenção militante, expressas no esforço de (a) análise dos impactos das políticas educacionais sobre os trabalhadores, e de (b) retomada dos estudos clássicos com vistas a (i) fundamentar a formação possível numa conjuntura de progressivo desmonte da educação pública e (ii) recuperar as lições das experiências históricas que apontam saídas para este quadro massacrante!

A Entrevista deste número é com Luis Eduardo Acosta, professor associado da Universidade Federal do Rio de Janeiro, ex-diretor do ANDES-SN. O roteiro elaborado por Maria de Fátima Rodrigues Pereira, Elza Peixoto e Gilcilene Barão, leva ao entrevistado a um interessante balanço da conjuntura mundial que auxilia no entendimento do movimento na conjuntura brasileira nos últimos anos. Caracterizando o momento como de "transição de uma forma social das sociedades capitalistas para outra caracterizada pela predomínio da forma social do capital financeiro, em particular do capital fictício que opera em favor das frações rentistas dos grandes capitalistas", Acosta destaca, entre outros aspectos e 
possibilidades que nos encontramos no "[...] segundo ciclo de contrarreformas neoliberais" que "[...] pode ser interpretado como uma tentativa de saída ilusória para a uma crise geral do capital que não tem saída porque já esgotou todas suas possibilidades de "progresso". Neste caso, estamos diante do colapso da sociedade capitalista, e, portanto o corolário é uma situação de barbárie, de decomposição social, caso não venha a emergir um sujeito histórico, a classe operária, capaz de conduzir a crise geral num sentido revolucionário".

O texto Clássico que selecionamos com o auxílio da pesquisadora Gilcilene Barão para este número é de Florestan Fernandes: "Padrões de dominação externa na América Latina". O autor faz uma cuidadosa análise das determinações dos processos históricos que colocam a América Latina em situação subordinada ao capitalismo em sua fase imperialista mais agressiva, visível desde o final dos anos 60 do século XX. Ante o projeto de "revolução dentro da ordem social" nos processos de desenvolvimento econômico e social da América Latina, Florestan apresenta outra possibilidade aberta que, numa conjuntura angustiante, desejamos destacar:

A outra resposta alternativa só pode surgir de uma rebelião popular e radical, de orientação socialista. A estranha combinação de uma ampla maioria de gente destituída, miserável ou quase-miserável, a uma exploração externa implacável e uma péssima utilização interna da riqueza, por minorias privilegiadas, gera um componente histórico imprevisível. A explosão social não é planejada com antecipação. Como em Cuba, ela pode sobrevir inesperada e dramaticamente.

A estrutura da sociedade e suas permanentes condições de anemia contêm os ingredientes básicos da desintegração: quando as forças da rebelião são liberadas, a ordem social não pode funcionar como um fator de autopreservação e de auto regeneração, porque ela não é desejada sequer pelos que tiram proveito das desigualdades e iniquidades existentes. A última alternativa, sem dúvida, abre caminho para a realização dos padrões mais elevados da razão humana e para a liberação real das sociedades latino-americanas. Todavia, ambas as soluções poderiam dar início a novas vias de evolução da América Latina, na direção de uma história de povos livres e independentes (FERNANDES, Florestan, 1975).

Duas Resenhas fecham este número: Camila Azevedo Souza traz "A relação dialética entre subjetividade e objetividade: materialismo histórico e psicologia histórico-cultural”; e Israel Ramos Moreira traz "Experiências pedagógicas para além do capital: análise do livro "fundamentos da escola do trabalho" de Pistrak".

A esta altura, a consciência de um processo profundo de crise nas relações de produção capitalistas não resolve os problemas objetivos dela decorrentes. Há largo passo entre a tomada de consciência de uma minoria de intelectuais que se desdobram para propagar suas análises, e a penetração destas análises nas massas de homens que se movem famintos concorrendo pelos meios de vida, produzindo-se - de cada um conforme a sua capacidade e as condições que encontram legadas pelo passado - resistência individuais e coletivas ${ }^{89}$. A barbárie encontra-se instalada como o denunciam o "dia do fogo" 90 no qual os latifundiários ligados à indústria de couro e carne, mineradoras e grileiros devassam a Amazônia, antes que a condição de constante instabilidade contenha os desmandos de um presidente inconsequente e irresponsável; como evidenciam o genocídio de índios, quilombolas, jovens, LGBTs ${ }^{91}$, mulheres e crianças da classe trabalhadora, cujas expressões mais recentes encontram-se na degola de presos sob a custódia do Estado92; como o provam o cárcere de Luiz Inácio Lula da Silva e o assassinato impune de Marielle Franco, Anderson Gomes e milhares e outros que se somam à estatística de lutadores e lutadoras do povo massacrados por lutar ${ }^{93}$. 
Um conjunto de ataques promovidos pela extrema-direita que tomou, em desespero ávido ${ }^{94}$, o poder de Estado no Brasil evidencia, no entanto, a esperança de que tamanha avidez faça revoltarem-se os que padecem... A lei do movimento de contrários encontra-se em fluxo... “A canga pode quebrar...”95

\begin{abstract}
Notas:
${ }^{1}$ Elza Margarida de Mendonça Peixoto, Professora Adjunto IV da FACED UFBA. Líder do Grupo de Estudos e Pesquisas Marxismo e Políticas de Trabalho e Educação. Editora da Revista Germinal: Marxismo e Educação em Debate. ORCID: https://orcid.org/0000-0002-4430-241X Email: elza.peixoto@ufba.br

2 Doutorando no Programa de Pós-Graduação da Faculdade de Educação (FACED-PPGE-UFBA). Licenciatura em História pela Universidade Estadual de Feira de Santana (2005). Especialização em Metodologia e Didática do Ensino da História e Cultura Afro-Brasileira e Africana (2009). Mestrado Acadêmico em Educação pela Universidade Estadual de Feira de Santana (2013). Desenvolve pesquisa com foco nas políticas educacionais e de valorização da carreira docente em Feira de Santana e na Bahia. Atualmente é professora da Rede Municipal de Ensino de Feira de Santana e da Rede de Ensino do Estado da Bahia. É membro do Grupo Marxismo e Políticas de Trabalho e Educação (UFBA). ORCID: https://orcid.org/0000-0002-4402-5061 Email: vanlopsi@gmail.com
\end{abstract}

${ }^{3}$ Doutorando no Programa de Pós-Graduação da Faculdade de Educação (FACED-PPGE-UFBA). Licenciatura em Educação Física pela Universidade Estadual de Feira de Santana (2006) e mestrado em Programa de Pós-Graduação em Educação pela Universidade Federal da Bahia (2013). Professor da Prefeitura Municipal de Feira de Santana e Professor Auxiliar a da Universidade Estadual de Feira de Santana ORCID: https://orcid.org/0000-0003-4178-8247 Email: espiritosanto.edson@gmail.com

${ }^{4}$ Doutorando no Programa de Pós-Graduação da Faculdade de Educação (FACED-PPGE-UFBA). Mestre em Educação pela Universidade Estadual de Feira de Santana (UEFS). Professor efetivo da Universidade do Estado da Bahia (UNEB). Pesquisador do Grupo de Estudos e Pesquisa em Marxismo, Políticas de Trabalho e Educação (GMTE-UFBA). Coordena o Grupo de Estudos, Pesquisa e Extensão em Educação, Educação Física, Esporte e Sociedade (GEPEFES-UNEB). Atualmente estuda a partir da Teoria Marxiana as relações, nexos e contradições entre o Estado, a Política Educacional brasileira e a Formação de professores na sociedade capitalista contemporânea. ORCID: https://orcid.org/0000-0003-3002-7207 Email: itamarcorpus@yahoo.com.br

5 Grupo de estudos e pesquisas Marxismo e Políticas de Trabalho e Educação - M. T. E. Disponível em: http://dgp.cnpq.br/dgp/espelhogrupo/195099 Acesso em: 03.09.2019. 05:00

${ }^{6}$ Em 13 de julho de 2017 foi aprovada a lei no 13.467 que alterou a Consolidação das Leis do Trabalho (CLT). Disponível em https://legis.senado.leg.br/norma/17728053/publicacao/17728664. Acesso em: 14.09.2019. Os principais pontos aprovados na Reforma Trabalhista foram: terceirização de qualquer ramo de atividade; criação do trabalho intermitente; redução do tempo de horário para o almoço; divisão das férias em até três períodos; validação de acordos individuais entre patrão e empregados, sem necessidade de mediação dos acordos coletivos por categoria.

${ }^{7}$ Revista Fórum. Reforma trabalhista: o pior ainda está por vir. Em entrevista à Revista Fórum concedida em 29.04.2018, o diretor técnico do Dieese, Clemente Ganz Lúcio, explicou como a reforma trabalhista começará a dar seus sinais em um futuro já certo de profundas transformações no mundo do trabalho. Disponível em: https://revistaforum.com.br/direitos/reforma-trabalhistao-pior-ainda-esta-por-vir/. Acesso em: 14.09.2019. Sobre os impactos da referida reforma o Jornal Brasil de Fato publicou a seguinte matéria em 12.09.2018: Ministério do Trabalho confirma: a reforma trabalhista é um desastre. Disponível em: https://www.brasildefato.com.br/2018/09/19/ministerio-do-trabalho-confirma-a-reforma-trabalhista-e-um-desastre/. Acesso em: 14.09.2019

8 Desde o Golpe de 2015 em que a Presidente Dilma Roussef foi destituída por frações de capitalistas ligados à Bancada BBB (bancada armamentista ("da bala"), bancada ruralista ("do boi") e à bancada evangélica (" da bíblia")), associados aos interesses rentistas (todos os setores interessados na manutenção elevada das taxas de juros bancários, por exemplo, setor de educação privada beneficiado pelos Programas FIES e PRONUNI), aos interessados no desmonte da Petrobrás e do monopólio desta corporação na extração do Petróleo no Brasil, entre outros setores, com a posse do vice Michel Temer, observa-se uma Reforma Constitucional em andamento. Somente o texto do projeto Future-se altera 16 Leis da Constituição de 1988.

${ }_{9}^{9}$ Sucessivos mandatos de reintegração de posse em áreas ocupadas há mais de décadas, constante imposição de multas aos sindicatos em greve, prisão política de líderes de movimentos estudantis e sindicais são expressão desta justiça de classe. Exemplo ilustrativo da ação truculenta da polícia e da posição parcial da justiça é o caso da comunidade de Pinheirinho, em São José dos Campos-SP, ocorrida no dia 22 de janeiro de 2012. Na oportunidade, o efetivo de 1800 policiais foi acionado para a remoção de cerca de 9000 moradores, para atender à ação movida por Naji Nahas, proprietário da então empresa falida Selecta. Carta Capital. Clima de Guerra na Ocupação Pinheirinho. Disponível em: https://www.cartacapital.com.br/sociedade/pm-e-moradores-se-enfrentamdurante-reintegracao/. Acesso em: 14/09/2019.

10 EXAME. The Economist destaca ligações e simpatia do clã Bolsonaro com milícias. Disponível em: https://exame.abril.com.br/brasil/the-economist-destaca-ligacoes-e-simpatia-do-cla-bolsonaro-com-milicias/ Acesso em 16.09.2019 08:13

11 A tensão na luta de classes explode nos meios de comunicação, restando claras as posições dos meios de comunicação. A campanha de difamação dos trabalhadores visa distorcer as finalidades dos movimentos de luta. A luta de classes também se evidencia na tentativa de eliminar os que denunciam os seus fragmentos, ver: Folha de São Paulo. Ameaçado, jornalista que 
denunciou 'Dia do Fogo' no Pará diz ter medo de morrer. Disponível em: https://www1.folha.uol.com.br/poder/2019/09/ameacado-jornalista-que-denunciou-dia-do-fogo-no-para-diz-ter-medo-demorrer.shtml Acesso em: 05.09.2019. 12:33. INTERCEPT Brasil. Disponível em: https://theintercept.com/brasil/ Acesso em: 05.09.2019. 12:33. El País. Repórteres Sem Fronteiras condena onda de ameaças a Greenwald, do 'The Intercept'. Disponível em: https://brasil.elpais.com/brasil/2019/07/31/politica/1564596524 615378.html Acesso em: 05.09.2019 12:46. REDE BRASIL ATUAL. ONU diz que jornalistas do 'The Intercept Brasil' correm risco de vida. Disponível em: https://www.redebrasilatual.com.br/politica/2019/09/onu-jornaistas-intercept-risco-de-vida/ Acesso em: 05.09.2019 12:45.

12 LEHER, Roberto. Banco Mundial: ajuste regressivo e antidemocrático. Correio da Cidadania. 28.11.2017. Disponível em: http://www.correiocidadania.com.br/2-uncategorised/12966-banco-mundial-ajuste-regressivo-e-antidemocratico Acesso em 22.08.2019.

Dirce Zan | Emmanuel Tourinho | Jamil Cury | Marcelo Knobel | Nelson Cardoso Amaral | Renato Pedrosa | Robert Verhine | Simon Schwartzman Relatório do Banco Mundial distorce dados e ignora a realidade do país, alertam especialistas. Jornal da UNICAMP. 30.11.2017. Disponível em: https://www.unicamp.br/unicamp/index.php/ju/noticias/2017/11/30/relatorio-dobanco-mundial-distorce-dados-e-ignora-realidade-do-pais-alertam Acesso em: 22.08.2019.

FREITAS, Luis Carlos de. Relatório do Banco Mundial é revisado por Nelson Amaral. Disponível em: https://avaliacaoeducacional.com/2017/11/27/relatorio-do-bm-e-revisado-por-nelson-amaral/ Acesso em: 22. 08. 2019.

AMARAL, Nelson. Uma análise do documento "Um Ajuste Justo: análise da eficiência e equidade do gasto público no Brasil". Disponível em: https://avaliacaoeducacional.files.wordpress.com/2017/11/analise-critica-bm-2017.pdf Acesso em 22.08.2019.

RETS. Rede Internacional de Educação de Técnicos em Saúde. Professores da UFBA fazem estudo detalhado do relatório do Banco Mundial. Disponível em: http://www.rets.epsjv.fiocruz.br/noticias/professores-da-ufba-fazem-estudo-detalhado-dorelatorio-do-banco-mundial Acesso em: 22.08.2019.

13 Banco Mundial. Um Ajuste Justo - Análise da Eficiência e Equidade do Gasto Público no Brasil 21.11.2017. Disponível em: https://www.worldbank.org/pt/country/brazil/publication/brazil-expenditure-review-report Acesso em: 22 de agosto de 2019. Instituto Construção. Construindo um Ajuste Justo Análise crítica do relatório do Banco Mundial "Um Ajuste Justo - Análise da Eficiência e Equidade do Gasto Público no Brasil" - Volume I: Síntese (2017). Disponível em: http:/ /institutoconstrucao.org/wpcontent/uploads/2018/04/construindo-um-ajuste-justo educacao-basica.pdf?utm source $=$ construindoperspectivas\&utm medium=PDF\&utm campaign=ajuste-justo\&utm content=educacao-basica Acesso em 22.08.2019.

14 PEREIRA, João Marcio Mendes. Dimensões da história do Banco Mundial como ator político, intelectual e financeiro Disponível em: http://www.scielo.br/scielo.php?script=sci arttext\&pid=S0102-311X2018000200301 Acesso em: 22. 08.2019.

15 LEHER, Roberto. Reforma do estado: o privado contra o público. Disponível em: http:/ www.scielo.br/scielo.php?script=sci arttext\&pid=S1981-77462003000200003\&lng=en\&nrm=iso\&tlng=pt Acesso em: 27/08/2019 $17 \mathrm{~h} 55$

${ }^{16}$ NOVOA, Jorge; BALANCO, Paulo. O estágio último do capital: a crise e a dominação do capital financeiro no mundo. Cad. CRH, Salvador , v. 26, n. 67, p. 87-104, abr. $2013 . \quad$ Disponível em http://www.scielo.br/scielo.php?script=sci arttext\&pid=S0103-49792013000100007\&lng=pt\&nrm=iso. $\quad$ Acesso em: 06.09. 2019. http://dx.doi.org/10.1590/S0103-49792013000100007. Banco Mundial e a Educação. Disponível em: http://www.histedbr.fe.unicamp.br/navegando/glossario/verb c banco mundial \%20e educacao\%20.htm. Acesso em: 14.09.2019. Ver o Projeto Future-se: Programa Instituto e Universidades Empreendedoras e Inovadoras - Future-se. Disponível em: http://estaticog1.globo.com/2019/07/19/programa futurese consultapublica.pdf Acesso em 04.09.2019 23:55.

17 Banco Mundial. Um Ajuste Justo - Análise da Eficiência e Equidade do Gasto Público no Brasil 21.11.2017. Disponível em: https://www.worldbank.org/pt/country/brazil/publication/brazil-expenditure-review-report Acesso em: 22 de agosto de 2019. Emenda Constitucional no 95 de 16.12.2016, que institui o Novo Regime Fiscal e dá outras providências. No governo Temer, esta emenda congelou os gastos sociais, principalmente, com saúde e educação. Disponível em: http://www.planalto.gov.br/ccivil 03/Constituicao/Emendas/Emc/emc95.htm Acesso em: 14.09.2019.

18 LEI $\mathrm{N}^{\circ}$ 13.243, DE 11 DE JANEIRO DE 2016. Disponível em: http://www.planalto.gov.br/ccivil 03/ Ato20152018/2016/Lei/L13243.htm Acesso em 03.09.2019. 17:57 ANDES - SN. Marco legal de ciência tecnologia e inovação. Disponível em: http://portal.andes.org.br/imprensa/documentos/imp-doc-1508946885.pdf Acesso em: 03.09.2019 18:04 ANDES- Neoliberalismo e ciência e tecnologia no Brasil. Disponível em: http://portal.andes.org.br/imprensa/documentos/imp-doc-186083876.pdf 03.09.2019 18:07

19 "O Capital” é a expressão que Karl Marx (1818-1883) extrai, em sua Crítica da economia política, para caracterizar o modo de produção a cujo estudo dedicou sua vida: o capitalismo. Mas é também a expressão que personifica o grupo político, a classe (e suas frações) que detém - na luta de classes entre Capital e Força de Trabalho, na correlação de forças - o controle dos meios de produção e por isso, do modo de produzir a vida, detendo também a hegemonia ideológica do modo de apreender estas relações de produção. Os que construímos Germinal mantemos viva esta matriz de análise revolucionária, contra todo o esforço de apagamento desta referência (pelo convencimento posto por todo o discurso pós-moderno e pela violência do silenciamento pelo encarceramento - Antonio Gramsci e Luis Carlos Prestes, por exemplo ou pela morte - Carlos Mariguela ${ }^{19}$ ). Um bom balanço dos fundamentos da crítica e do combate ao marxismo pode ser reconhecido em: EVANGELISTA, João. Crise do marxismo e irracionalismo pós-moderno. São Paulo: Cortez, 1992.

20 O Atlas da Violência 2019, produzido pelo IPEA, abre os dados explicando: "Segundo os dados oficiais do Sistema de Informações sobre Mortalidade, do Ministério da Saúde (SIM/MS), em 2017 houve 65.602 homicídios no Brasil, o que equivale a uma taxa de aproximadamente 31,6 mortes para cada cem mil habitantes. Trata-se do maior nível histórico de letalidade violenta intencional no país", que atinge particularmente à juventude negra e pobre, às mulheres e aos LGBT. Disponível em : http://www.ipea.gov.br/atlasviolencia/arquivos/downloads/6537-atlas2019.pdf Acesso em: 29.08.2019. 23:58. O problema é exposto com mais abrangência em: Plataforma Política. Juventude contra a violência. "Enfrentamento ao genocídio da juventude negra". Disponível em: https://juventudescontraviolencia.org.br/plataformapolitica/quem-somos/eixos- 
programaticos/enfrentamento-ao-genocidio-da-juventude-negra/ Acesso em 30.08.2019 00:16. Uma interessante análise dos dados aparece também em: GELEDÉS - Instituto da mulher negra. "O genocídio da juventude negra no Brasil". Disponível em: https://www.geledes.org.br/o-genocidio-da-juventude-negra-no-brasil/ Acesso em 30.08.2019. 00:11. Em matéria divulgada pela Folha de São Paulo, escrita por Tatiane dos Anjos (22.11.1017), a barbárie respira negócio: "Racismo no Brasil e o Extermínio da Juventude Negra". Disponível em: https://www1.folha.uol.com.br/empreendedorsocial/colunas/2017/11/1937240racismo-no-brasil-e-o-exterminio-da-juventude-negra.shtml Acesso em: 29.08.2019 23:46.

21 O índice de força de trabalho desempregada no Brasil é o maior da história do país! Em 03/04/2018 o Jornal Brasil de Fato divulgou notícia com título: 65,6 milhões de pessoas não trabalham nem procuram emprego. Disponível em: https://www.brasildefato.com.br/2018/08/03/dados-do-ibge-mostram-que-numero-de-pessoas-fora-da-forca-de-trabalhocresceu/Acesso em: 29.08.2019 19h51. Em 29 de agosto de 2019, a matéria da Carta Capital denuncia: "Desemprego: 1 em cada 4 pessoas procura trabalho há pelo menos dois anos". Disponível em: https://www.cartacapital.com.br/economia/desemprego1-em-cada-4-pessoas-procura-trabalho-ha-pelo-menos-2-anos/ Acesso em 29.08.2019. 22:20. Desde que o IBGE passou para o controle da iniciativa privada, os dados emitidos por aquela agencia deixaram de ser confiáveis. O Jornal Folha de São Paulo, em 15 de agosto de 2019, reporta: 3,3 milhões de desempregados buscam trabalho há dois anos, diz IBGE. Disponível em: https://www1.folha.uol.com.br/mercado/2019/08/desemprego-recua-em-10-estados-no-segundo-trimestre-diz-ibge.shtml Acesso em: 29.08.2019. 22:33. Em 03.04.2019 o Jornal El País divulga a matéria: 14 horas numa fila por um emprego: "As contas e a barriga não esperam" Disponível em: https://brasil.elpais.com/brasil/2019/04/02/politica/1554156937 233006.html Acesso em 29.8.2019 20:13. Os dados são difusos, considerando três categorias: desempregados, desalentados (que já não procuram emprego) e subocupados vivendo na informalidade. O Jornal Nexo analisa em 02 de agosto de 2019: "O que dizem os números do desemprego brasileiro" Disponível em: https://www.nexojornal.com.br/expresso/2019/08/02/O-que-dizem-os-números-dodesemprego-brasileiro Acesso em: 29.08.2019. Em "Veja: 3,3 milhões de brasileiros estão há 2 anos ou mais em busca de emprego". Disponível em: https://veja.abril.com.br/economia/33-milhoes-de-brasileiros-estao-ha-2-anos-ou-mais-sememprego/ Acesso em: 29.08.2019. 22:04. Ou ainda: Exame: "Quase 9 em 10 jovens empregados no último ano estão informais" Disponível em: https://exame.abril.com.br/economia/quase-9-em-10-jovens-que-acharam-emprego-no-ultimo-ano-estaoinformais/ Acesso em 29.08.2019. 22:04. A Carta de Conjuntura do IPEA, em junho de 2019, Mercado de Trabalho: Taxa de Desemprego. Disponível em: http://www.ipea.gov.br/cartadeconjuntura/index.php/tag/taxa-de-desemprego/ Acesso em: 29.08.2019. 22:04. Mas os cálculos feitos pelos meios de comunicação mais ligados aos interesses capitalistas consideram dentro dos números da população economicamente ativa, os jovens a partir dos 14 anos de idade, o que aumenta imensamente o número dos excluídos de qualquer do trabalho estável.

22 A gana de acumulação e exploração da força de trabalho não se esgota mesmo com um imenso contingente de força de trabalho fora do mercado formal. Em que pese o altíssimo índice de desemprego, e, portanto, de falta de massa salarial, a imprensa noticia que recentemente um balanço do Instituto Locomotiva constatou que cerca de 40 milhões de brasileiro não possuem contas bancárias. A notícia (com índices que variam de forma surpreendente" foi propagada por vários meios de comunicação: Gazeta do Povo (19/08/2019) Um em cada três brasileiros não têm conta em banco. "[...] 86\% dos desbancarizados estão concentrados nas classes econômicas C, D e E. Sete em cada dez, ou $69 \%$ do total consultado, são negros ou pardos. Além disso, seis em cada dez desbancarizados são mulheres, o que representa $59 \%$ do total". Disponível em: https://www.gazetadopovo.com.br/economia/breves/um-em-cada-tres-brasileiros-nao-tem-conta-em-banco/ Acesso em: 29.08.2019 22:40. O Sindicato dos Bancários de Alagoas (vinculado à CUT) revela em 2013 o motivo de tanto alarde e surpresa: "Neste ano, R $\$ 665$ bilhões vão passar pelas mãos - ou melhor, pelos bolsos - dos 55 milhões de brasileiros que não têm conta em banco. Esses brasileiros representam 39,5\% da população adulta do país, segundo estudo do instituto Data Popular. Os dados serão apresentados hoje durante seminário em São Paulo para discutir o impacto do crédito no comportamento de consumo da nova classe média, dona hoje de 103 milhões de cartões de crédito no país. O valor que passa à margem do sistema bancário brasileiro (R \$ 665 bilhões) equivale quase ao PIB da Colômbia, segundo informações do Banco Mundial. "O que surpreende é que, por mais que o processo de bancarização tenha crescido, quatro em cada dez brasileiros ainda não possuem conta-corrente ou poupança. E esse número é ainda maior nas classes mais baixas", afirma Renato Meirelles, sócio e diretor do instituto. QUEM SÃO Metade dos brasileiros sem conta em banco está na classe média --são 29 milhões de pessoas que fazem parte de famílias com renda per capita de $\mathrm{R} \$ 291$ a $\mathrm{R} \$ 1.019$. O critério de classificação por faixa de renda é o mesmo adotado pelo governo. Outros 11\% dos sem conta em banco (6 milhões de pessoas) estão na classe alta, e 37\% (20 milhões), na baixa. Um terço da população "desbancarizada" tem de 40 a 59 anos --pessoas em sua maior parte (65\%) com ensino fundamental completo. Quase metade desses brasileiros está fora do mercado de trabalho --são donas de casa, desempregados, estudantes e aposentados. Para o levantamento, foram entrevistadas 2.006 pessoas de 53 cidades entre os meses de fevereiro e março deste ano." (Disponível: http://bancariosal.org.br/noticia/25658/sem-conta-em-banco-milhoes-de-brasileiros-giram-r-bilhoes Acesso em: 29.08 .2019 22h54). Em 29.08.2019, a Revista Época Negócios revela que os bancos estão avançando mesmo nesta grave situação de informalidade, trazendo no título da matéria: "Brasil tem 45 milhões de desbancarizados, diz pesquisa. Eles movimentam R\$ 817 bilhões por ano". Mais adiante: "Pesquisa realizada pelo Instituto Locomotiva revela a existência no Brasil de 45 milhões de desbancarizados, ou seja, brasileiros que não movimentam a conta bancária há mais de seis meses ou que optaram por não ter conta em banco. Isso significa que de cada três brasileiros, um não possui conta bancária. De acordo com a sondagem, esse grupo movimenta anualmente no país mais de $\mathrm{R} \$ 800$ bilhões." O cinismo é escrachado: "O Brasil sairia mais rápido da crise econômica se a bancarização crescesse". Disponível em: https://epocanegocios.globo.com/Brasil/noticia/2019/08/brasil-tem-45-milhoesde-desbancarizados-diz-pesquisa.html Acesso em 29.08.2019 23:14. Em 06/06/2018 o Estadão publica a matéria: Startups brasileiras agora miram os "sem banco". O sub-título da matéria: "Brasileiros sem acesso aos serviços financeiros somam 60 milhões de pessoas - um mercado cobiçado por startups". Detalha: "Como muitos negócios da população desbancarizada são informais e a maioria das pessoas das classes B e C não consegue comprovar renda, esse público é negligenciado pela rede bancária tradicional. "Só agora o estigma de que esse mercado não é rentável começa a ser quebrado, até mesmo porque a tecnologia permite que as instituições operem com custos mais baixos", afirma Bruno Diniz, coordenador do núcleo de fintechs da Associação Brasileira de Startups (ABStartups)". Disponível em: https://link.estadao.com.br/noticias/inovacao,startups-mirambrasileiros-que-nao-tem-acesso-ao-sistema-bancario,70002339265 Acesso em: 29.08.2019 23:38. 
${ }^{23}$ Brasil de Fato. (17.12.2018) A política econômica de Bolsonaro: entre o nacionalismo de fachada e o neoliberalismo. Disponível em: $\quad$ https://www.brasildefato.com.br/2018/12/17/turma-do-paulo-guedes-quer-aprofundar-a-cartilha-neoliberal-diz-ledapaulani/ Acesso em: 30.08.2019 09:22. Em campanha pró Bolsonaro, a revista Exame. (28.05.2018) O que pensa Paulo Guedes, o cérebro econômico de Jair Bolsonaro. "Nas contas de Guedes, a participação do governo nas estatais renderia hoje cerca de 800 bilhões de reais, capaz de abater cerca de 20 por cento da dívida pública federal, calculada em 3,6 trilhões de reais." Disponível em: https://exame.abril.com.br/brasil/o-que-pensa-paulo-guedes-o-cerebro-economico-de-jair-bolsonaro/ Acesso em 30.08.2019. Carta Capital. (30.08.2019) "Neoliberalismo vive fase autoritária pois concentra renda". Disponível em: Nas contas de Guedes, a participação do governo nas estatais renderia hoje cerca de 800 bilhões de reais, capaz de abater cerca de 20 por cento da dívida pública federal, calculada em 3,6 trilhões de reais. Disponível em: https://www.cartacapital.com.br/economia/neoliberalismo-vive-fase-autoritaria-pois-concentra-renda/ Acesso em: 30.08 .2019 09h42. Mauro Iasi, no Blog da Boitempo alerta: "O caráter burlesco, para o qual a figura tosca do Presidente contribui de forma decisiva, pode desviar nossa atenção do essencial. O ultraliberalismo do Ministro da Economia Paulo Guedes e sua sanha em desmontar o Estado, aniquilar direitos, destruir políticas públicas, diria Weber, não são mais que meios irracionais para atingir fins racionalmente calculados." Disponível em: https://blogdaboitempo.com.br/2019/02/14/o-fetichismo-e-as-formas-politicas-Oestado-burgues-na-forma-burlesca/ Acesso em: 30.08.2019. 09h49.

${ }^{24}$ NOVOA, Jorge; BALANCO, Paulo. O estágio último do capital: a crise e a dominação do capital financeiro no mundo. Cad. CRH, Salvador , v. 26, n. 67, p. 87-104, abr. 2013 . Disponível em http://www.scielo.br/scielo.php?script=sci arttext\&pid=S0103-49792013000100007\&lng=pt\&nrm=iso $\quad$ acessos em 06 set. 2019. http://dx.doi.org/10.1590/S0103-49792013000100007. (REFERÊNCIA FOI PARA A NOTA 09).

25 No Brasil, as evidências quanto a este desespero expressam-se no Impeachment de Dilma Roussef, comprovando a pressa dos capitalistas em obter reformas que lhes garantam as condições para extração intensiva de mais valia. Expressam-se também no pool de empresas que apoiou Bolsonaro como candidato. Na pressa de realizar uma queimada que colocou o Brasil na mira das grandes potências internacionais, evidenciando disputa de interesses intra-capitalistas!

${ }^{26}$ Matéria do G1 de 14/08/2019 19h24 denuncia que na semana de 11 a 17/08/2019: "RJ teve pelo menos 6 jovens mortos a tiros em 5 dias - Todas as famílias negam qualquer envolvimento com o crime. Em várias das ocasiões, havia operações policiais na região." Entre os mortos, a jovem Margareth Teixeira de 17 anos, encontrada morta após o tiroteio entre policiais e membros da comunidade considerados "marginais" e mebros do "narcotráfico". O filho de Margareth de 1 ano ficou ferido no pé. Disponível: https://g1.globo.com/ri/rio-de-janeiro/noticia/2019/08/14/ri-teve-pelo-menos-6-jovens-mortos-a-tiros-em-cinco-dias.ghtml Acesso em: 30.08.2019 08:53. A GloboNews divulgou em o pronunciamento da Política Militar (Mauro Flies) e do Secretário de Segurança do Governo do Estado Rio de Janeiro (Cleiton Rodrigues), evidenciam a indiferença com a vida dos trabalhadores. Os policiais são tratados como cidadãos com direito de defesa. Os membros da comunidade considerados antecipadamente como: "em situação suspeita" de ligações com narcotráfico. O secretário os designa como "narcoterrorristas que estão desafiando o poder do Estado". Este devem ser mortos, e aqueles que estiverem próximos são considerados membros desta "máfia". Disponível: $\quad$ http://g1.globo.com/globo-news/jornal-globo-news/videos/v/porta-voz-da-pm-rj-defende-investigacaotransparente-de-morte-de-jovens-no-rio/7842291/ Acesso em: 30.08.2019 09:04.

27 Banco Mundial. Um Ajuste Justo - Análise da Eficiência e Equidade do Gasto Público no Brasil 21.11.2017. Disponível em: https://www.worldbank.org/pt/country/brazil/publication/brazil-expenditure-review-report Acesso em: 22 de agosto de 2019. CUT. Dieese: Reforma da Previdência exige mais sacrifícios das mulheres. Disponível em: https://www.cut.org.br/noticias/dieese-reforma-da-previdencia-exige-mais-sacrificios-das-mulheres-77fa Acesso em: 1.09.2019. Gazeta Web Notícias (09.07.2019). Planalto: todo mundo vai dar sua "cota de sacrifício" na Previdência. Disponível em: https://gazetaweb.globo.com/portal/noticia/2019/07/planalto-todo-mundo-vai-dar-sua-cota-de-sacrificio-na-

previdencia 80500.php Acesso em: 01.09.2019. 22:03. BRASIL DE FATO. Bolsonaro e Guedes devem sacrificar trabalhadores e estrangular Estado. Disponível em: https://www.brasildefato.com.br/2018/11/21/bolsonaro-e-guedes-devem-sacrificartrabalhadores-e-estrangular-estado/ 01.09.2019. 22:05. VALOR Econômico (203.2019). CNBB: Reforma da previdência de Bolsonaro sacrifica os mais pobres. Disponível em: https://www.valor.com.br/reformadaprevidencia/6187237/cnbb-reformada-previdencia-de-bolsonaro-sacrifica-os-mais-pobres Acesso em: 1.09.2019. 22:11.

${ }_{28}$ Marx, Karl. O Capital: crítica da economia política. Rio de Janeiro: Bertrand Brasil, 1989.

${ }^{29}$ INFOMONEY. Taurus oferece 20\% de desconto em armas durante a semana do Brasil. Publicado em 06.09.2012. 12h12. Disponível em: https://www.infomoney.com.br/taurusarmas/noticia/9329535/taurus-vai-dar-20-de-desconto-em-armasdurante-a-semana-do-brasil Acesso em: 13.9.2019 13:46. A matéria foi publicada com o mesmo título também em: ECONOMIA UOL. https://economia.uol.com.br/noticias/redacao/2019/09/06/taurus-promocao-semana-do-brasil.htm Acesso em: 13.9.2019 13:46. No site da Taurus Armas, sob o mesmo título, encontramos: "A fabricante de armas Taurus está oferecendo $20 \%$ de desconto durante a semana do Brasil, evento de promoções criado pelo Governo Federal para estimular o consumo" Disponível em: https://taurusarmas.com.br/pt/noticias/taurus-oferece-20-de-desconto-em-armas-durante-asemana-do-brasil Acesso em: 13.9.2019 13:46.

30 BOITO, Armando. A hegemonia neoliberal no Governo Lula. Disponível em: http://files.adrianonascimento.webnode.com.br/2000001705831f592c5/Boito\%20Jr,\%20Armando.\%20A\%20hegemonia\%20neoliberal\%20no\%20governo\%20Lula..pdf Acesso em: 30.08.2018. 11:58.

31 CARTA CAPITAL. A última fronteira. The Observer - A disputa pela Groelândia delineia a nova batalha colonialista entre as potências mundiais. 04.09.2019. Anoi XXV, N. 1070. P. 50-51.

32 OXFAM Brasil. Super-ricos estão ficando com quase toda riqueza, às custas de bilhões de pessoas. Disponível em: https://www.oxfam.org.br/noticias/super-ricos-estao-ficando-com-quase-toda-riqueza-as-custas-de-bilhoes-de-pessoas 05.09.2019 01:06.

33 Jornal Brasil de Fato divulgou notícia com título: 65,6 milhões de pessoas não trabalham nem procuram emprego. Disponível em: https://www.brasildefato.com.br/2018/08/03/dados-do-ibge-mostram-que-numero-de-pessoas-fora-da-forca-de-trabalhocresceu/Acesso em: 29.08.2019 19h51. Em 29 de agosto de 2019, a matéria da Carta Capital denuncia: "Desemprego: 1 em cada 
4 pessoas procura trabalho há pelo menos dois anos". Disponível em: https://www.cartacapital.com.br/economia/desemprego1-em-cada-4-pessoas-procura-trabalho-ha-pelo-menos-2-anos/ Acesso em 29.08.2019. 22:20.

34 PEC 241/2016. EC 95/2016.

35 OFFE, Clauss. Sistema educacional, sistema ocupacional e política da educação. Contribuição à determinação das funções sociais do sistema educacional. Educação e sociedade, n. 35, abril. 1990. AGÊNCIA BRASIL. Capes anuncia corte de 5.613 bolsas de pós-graduação para este ano. Disponível em: http://agenciabrasil.ebc.com.br/educacao/noticia/2019-09/capes-anuncia-cortede-5613-bolsas-de-pos-graduacao-para-este-ano Acesso em: 6.09.2019. 11:07 ANPG. ANPG e APGS repudiam cortes na capes e convocam a resistência nas ruas em 7 de setembro. Disponível em: http://www.anpg.org.br/02/09/2019/anpg-repudia-cortesna-capes-e-convoca-a-resistencia-nas-ruas-em-7-de-setembro/ Acesso em: 06.09.2019 11:11.

36 Carta Capital. Governo Bolsonaro dinamita mundo do trabalho e põe o Brasil de joelhos. Disponível em: https://www.cartacapital.com.br/economia/governo-bolsonaro-dinamita-mundo-do-trabalho-e-poe-o-brasil-de-joelhos/ Acesso em: 29.8.2019. 22:25.

37 UNICAMP. Instituto de Economia. CESIT: Dimensões críticas da reforma trabalhista no Brasil. Disponível em: https://www.eco.unicamp.br/index.php/noticias/372-dimensoes-criticas-da-reforma-trabalhista-no-brasil-27-04 Acesso em: 5.09.2019 01:14

38 SILVA, Mauri Antonio da. Análise crítica da proposta de reforma da previdência social no Brasil entre os anos 2016 e 2018 Disponível em: http://www.scielo.br/scielo.php?script=sci arttext\&pid=S0101-66282019000200213 Acesso em: 05.09.2019 01:19. Auditoria Cidadã da dívida. Economista da ACD desmonta argumentos neoliberais em defesa da Reforma da Previdência. Disponível em: https://auditoriacidada.org.br/video/economista-da-acd-desmonta-argumentos-neoliberais-em-defesa-dareforma-da-previdencia/ Acesso em: 05.09.2019 01:24.

${ }^{39}$ CUT. (04.11.2015) Fechar escolas e superlotar salas de aulas é um crime! Disponível em: https://www.cut.org.br/artigos/fecharescolas-e-superlotar-salas-de-aulas-e-um-crime-fdd0 Acesso em: 06.09.2019 10:34

40 Os ataques à educação pública no marco das reformas neoliberais na década de 1990, foram configurados com argumento ideológico de seus defensores de uma suposta crise do Estado. Estas reformas tiveram como marco regulatórios o Plano Diretor de Reforma do Estado de 1995 e Emenda Constitucional no 19/1998, os quais apontaram as organizações sociais de direito privado, ou públicas não-estatais, como instituições responsáveis pela oferta de educação. A partir da década de 2000 , as instituições ligadas ao capital passaram a agir mais organicamente, por dentro do governo, dando a direção das políticas educacionais. Esse processo ganhou legitimidade com a aprovação da lei federal $n^{\circ} 11.079 / 04$ que regulamentou as Parcerias Publica Privada - PPP; Com o Decreto n ${ }^{\circ}$ 6.094, de 24 de abril de 2007, "Plano de Metas Compromisso Todos pela Educação", uma plataforma de diretrizes e ações do Movimento Todos Pela Educação, organização mais representativa das diversas frações da burguesia passaram a orientar as políticas educacionais em todo o território nacional. Na educação profissional foi a promulgação da Lei no 12.513, de 26 de outubro de 2011, que instituiu o Programa Nacional de Acesso ao Ensino Técnico e Emprego (Pronatec). Destaca-se que, a operacionalização deste programa se deu prioritariamente por meio da parceria públicoprivada, tendo no Sistema S seu principal parceiro e beneficiário dos recursos financeiros. No governo Temer, o ataque se fez, principalmente, com o congelamento dos gastos sociais (Emenda Constitucional n $n^{\circ}$ 95/2016); a Reforma do Ensino Médio (transformação da Medida Provisória 746/2016 na lei no 13.415 e de 16 de fevereiro de 2017); a Resolução CNE/CP nº 02 de 22 de dezembro de 2017, que instituiu a implantação da Base Nacional Comum Curricular da Educação e nas alterações na legislação trabalhista com a promulgação da lei no 13.467, de 13 de julho de 2017. EVANGELISTA, Olinda; LEHER, Roberto. Todos pela Educação e o episódio Costin no MEC: a Pedagogia do capital em ação na política educacional brasileira. Trabalho Necessário, ano 10, No 15/2012. Disponível em http://periodicos.uff.br/trabalhonecessario/article/view/6865/5148. Acesso 31.08.2019. Um julho do corrente ano, o MEC anunciou o "Programa Compromisso Nacional pela Educação Básica", em parceria com a CONSED e UNDIME, o qual indica a construção de 108 escolas militares até o ano de 2023 , em todas as 27 unidades da federação. A militarização vem sendo proposta, segundo os formuladores do programa, através de uma orientação que combina regime cívico e militar, ao delegar a administração e gestão das escolas à militares da reserva. Nota Pública da CNTE sobre o "Programa Compromisso Nacional pela Educação Básica" denunciando o viés de militarização e a mercantilização da educação pública. Disponível em: ttps://www.cnte.org.br/index.php/menu/comunicacao/posts/notas-publicas/72045-mec-lanca-Ocompromisso-nacional-pela-educacao-basica-assumindo-seu-vies-de-ampliar-a-militarizacao-e-a-mercantilizacao-da-educacaopublica-brasileira. Acesso em 29.08.2019. No dia 05.09.2019, o presidente Jair Bolsonaro assina decreto para a criação de escolas cívico-militares. Governo lança programa para incentivar criação de escolas cívico-militares em todo país. Disponível em: https://g1.globo.com/politica/noticia/2019/09/05/governo-lanca-programa-para-incentivar-criacao-de-escolas-civicomilitares-no-pais.ghtml; Bolsonaro assina decreto para 'militarizar' 216 escolas em quatro anos. Disponível em: https://veja.abril.com.br/politica/bolsonaro-assina-decreto-para-militarizar-216-escolas-em-4-anos/; Sobre o programa de incentivo a militarização das escolas, em entrevista à Carta Capital, no dia 12.09.2019, Miguel Arroyo diz que escolas militarizadas criminalizam infâncias populares. Disponível em: https://www.cartacapital.com.br/educacao/miguel-arroyo-escolasmilitarizadas-criminalizam-infancias-populares/. Acesso em 14.09.2019.

40 "Os empresários, segundo Mercadante, terão um papel importante no Programa Nacional de Acesso ao Ensino Técnico e Emprego (Pronatec) e no processo de formação dos trabalhadores e seu aprimoramento tecnológico" Disponível em: .http://portal.mec.gov.br/index.php?option=com content\&view=article\&id=17492. Acesso em 01.09.2019; De acordo com o Relatório do Tribunal de Conta da União de 2015, "No período de 2011 a 2014, foram destinados ao programa R \$ 17,7 bilhões e foram efetivamente executados R \$ 10,2 bilhões (valores liquidados). A maior parte desses recursos foi direcionada ao BolsaFormação, que recebeu previsão orçamentária de $\mathrm{R} \$ 8,4$ bilhões, dos quais $\mathrm{R} \$ 8,0$ bilhões foram executados, o que correspondente a $78 \%$ do total executado. Os maiores executores do Bolsa-Formação são os integrantes do Sistema S, o que seria decorrente da estrutura operacional dessas entidades, caracterizada pela capilaridade e capacidade de interiorização no país. Juntos, Senai, Senac, Senat e Senar receberam, desde o início do programa, R \$ 5,8 bilhões dos R \$ 8,0 bilhões executados". Disponível em: http://webcache.googleusercontent.com/search?q=cache:YUHuJIO fcsJ:www.tcu.gov.br/Consultas/Juris/Docs/judoc/Acor $\mathrm{d} / 20151211 / \mathrm{AC} 333051 \_15$ P.doc $+\& \mathrm{~cd}=1 \& \mathrm{hl}=\mathrm{pt}-\mathrm{BR} \& \mathrm{ct}=\mathrm{clnk} \& \mathrm{gl}=\mathrm{br}$. Acesso em 01.09.2019. 
41 O Globo. Medida Provisória para regulamentar educação em casa foi feita por associação de ensino domiciliar. Disponível em: https://oglobo.globo.com/sociedade/educacao/medida-provisoria-para-regulamentar-educacao-em-casa-foi-feita-porassociacao-de-ensino-domiciliar-23411397 Acesso em: 06.09.2019 10:41. RIGHETTI, Sabine. Ensino em casa, PB - Problemas Brasileiros, ano 56, ago/set. 2019, p. 17-18. ABRUCIO, Fernano. "O ensino domiciliar é um fenômeno minoritário no mundo, mas que cresce, especialmente em grupos religiosos”. Ensino em casa, PB - Problemas Brasileiros, ano 56, ago/set. 2019 , p. 19.

42 G1 Política. CNJ registra pelo menos 812 mil presos no país; $41,5 \%$ não tem condenação. Disponível em: https://g1.globo.com/politica/noticia/2019/07/17/cnj-registra-pelo-menos-812-mil-presos-no-pais-415percent-nao-temcondenacao.ghtml Acesso em: 05.09.2019 01:27. Carta Capital. Brasil, terceira maior população carcerária, aprisiona cada vez mais. Disponível em: https://www.cartacapital.com.br/sociedade/brasil-terceira-maior-populacao-carceraria-aprisiona-cada-vezmais/ Acesso em: 05.09.2019 01:27.

43 O Atlas da Violência 2019, produzido pelo IPEA, abre os dados explicando: "Segundo os dados oficiais do Sistema de Informações sobre Mortalidade, do Ministério da Súde (SIM/MS), em 2017 houve 65.602 homicídios no Brasil, o que equivale a uma taxa de aproximadamente 31,6 mortes para cada cem mil habitantes. Trata-se do maior nível histórico de letalidade violenta intencional no país", que atinge particularmente à juventude negra e pobre, às mulheres e aos LGBT. Disponível em : http://www.ipea.gov.br/atlasviolencia/arquivos/downloads/6537-atlas2019.pdf Acesso em: 29.08.2019. 23:58. O problema é exposto com mais abrangência em: Plataforma Política. Juventude contra a violência. "Enfrentamento ao genocídio da juventude negra". Disponível em: https://juventudescontraviolencia.org.br/plataformapolitica/quem-somos/eixosprogramaticos/enfrentamento-ao-genocidio-da-juventude-negra/ Acesso em 30.08.2019 00:16. Uma interessante análise dos dados aparece também em: GELEDÉS - Instituto da mulher negra. "O genocídio da juventude negra no Brasil". Disponível em: https://www.geledes.org.br/o-genocidio-da-juventude-negra-no-brasil// Acesso em 30.08.2019. 00:11. Em matéria divulgada pela Folha de São Paulo, escrita por Tatiane dos Anjos (22.11.1017), a barbárie respira negócio: "Racismo no Brasil e o Extermínio da Juventude Negra". Disponível em: https://www1.folha.uol.com.br/empreendedorsocial/colunas/2017/11/1937240racismo-no-brasil-e-o-exterminio-da-juventude-negra.shtml Acesso em: 29.08.2019 23:46.

${ }_{44}^{4}$ Resolução CNE/CP no 2, de 22 de dezembro de 2017. Institui e orienta a implantação da Base Nacional Comum Curricular, a ser respeitada obrigatoriamente ao longo das etapas e respectivas modalidades no âmbito da Educação Básica. Disponível em: http://basenacionalcomum.mec.gov.br/images/historico/RESOLUCAOCNE CP222DEDEZEMBRODE2017.pdf. Acesso em: 14.09.2019; Resolução no 4, de 17 de dezembro de 2018. Institui a Base Nacional Comum Curricular na Etapa do Ensino Médio (BNCC-EM), como etapa final da Educação Básica, nos termos do artigo 35 da LDB, completando o conjunto constituído pela BNCC da Educação Infantil e do Ensino Fundamental, com base na Resolução CNE/CP n ${ }^{\circ} 2 / 2017$, fundamentada no Parecer CNE/CP no 15/2017. Disponível em: http://portal.mec.gov.br/docman/dezembro-2018-pdf/104101-rcp004-18/file. Acesso em: 14.09.2019. De acordo com Luiz Carlos de Freitas, “A Base Nacional Comum Curricular na política educacional do MEC tem a finalidade de promover tanto o controle da aprendizagem dos estudantes, como dos professores e da própria escola. Neste processo, o que é relevante para esta política é a geração dos chamados objetivos de aprendizagem (os chamados "direitos de aprendizagem")". Disponível em: https://avaliacaoeducacional.com/2017/04/07/bncc-como-os-objetivos-seraorastreados/. Acesso em: 14.09.2019. Um amplo acervo disponível para a crítica da BNCC no Ensino Médio encontra-se no Observatório do Ensino Médio. Disponível em: http://www.observatoriodoensinomedio.ufpr.br/. Acesso em: 14.09.2019.

${ }^{45}$ FRIGOTTO, Gaudêncio (org.) Escola “sem” Partido. Rio de Janeiro: LPP/UERJ, 2017.

${ }^{46}$ Escola sem Partido. Educação sem doutrinação. Disponível em: http://escolasempartido.org/flagrando-o-doutrinador Acesso em: 01.09.2019. 22:36. Programa Escola sem partido. Disponível em: https://www.programaescolasempartido.org Acesso em: 01.09.2019. 22:39. UBES. Escola sem mordaça. Disponível em: http://ubes.org.br/tag/escola-sem-mordaca/ Acesso em: 01.09.2019. 22:43. ANDES. Frente "Escola Sem Mordaça" lança novo site com canal para denúncias. Disponível em: https://www.andes.org.br/conteudos/noticia/frente-nacional-escola-sem-mordaca-lanca-novo-site-com-canal-para-denuncias1 Acesso em 01.09.2019. 22:47 EXTRA CLASSE (10.11.2016). Escola Sem Partido X Escola Sem Mordaça. Disponível: https://www.extraclasse.org.br/educacao/2016/11/escola-sem-partido-x-escola-sem-mordaca/ Acesso em: 01.09.2019 22:52. VERMELHO. Escola livre e escola sem partido: as respostas ao escola sem partido. Disponível em: http://www.vermelho.org.br/noticia/318522-1 Acesso em: 01.09.2019 22:55. PCB. Escola Sem Partido: o interesse privado sufoca a esfera pública. Disponível em: https://pcb.org.br/portal2/20260/escola-sem-partido-o-interesse-privado-sufoca-aesfera-publica/ Acesso em: 01.09.2019. 22:58. Entrevista em 20.04.2016 com Fernando de Araújo Penna sobre o PL "Escola sem partido". Disponível em: http://www.anped.org.br/news/entrevista-com-fernando-de-araujo-penna-escola-sem-partido-serieconquistas-em-risco. Acesso em: 14.09.2019. DOSSIÊ ESCOLA SEM PARTIDO. Disponível em: http://www.epsjv.fiocruz.br/noticias/dossie/escola-sem-partido. Acesso em: 14.09.2019.

47 Uma síntese sobre este debate pode ser obtida na obra de Ricardo Antunes Adeus ao trabalbo. Campinas: UNICAMP, 1995.

48 A quem chamam de "colaborador".

49 Ver de Karl Marx as obras "Introdução à crítica da filosofia do direito de Hegel" e "Manifesto do Partido Comunista".

50 PONCE, Aníbal. Educação e luta de classes. São Paulo: Cortez, 2007.

SAVIANI, D. História das ideias pedagógicas no Brasil. Campinas, Autores Associados, 2007.

${ }^{51}$ IPRI. As 15 maiores economias do mundo. Disponível em: http://www.funag.gov.br/ipri/index.php/o-ipri/47-estatisticas/94as-15-maiores-economias-do-mundo-em-pib-e-pib-ppp Acesso em 13/09/2019 07:36

52 NAÇÕES UNIDAS BRASIL. UNESCO: 750 milhões de jovens e adultos no mundo são analfabetos. Disponível em: https://nacoesunidas.org/unesco-750-milhoes-de-jovens-e-adultos-no-mundo-sao-analfabetos/ Acesso em: 13.09.2019 07:25 O GLOBO SOCIEDADE. Brasil ainda tem 11,3 milhões de analfabetos. Disponível em: https://oglobo.globo.com/sociedade/educacao/brasil-ainda-tem-113-milhoes-de-analfabetos-23745356 Acesso em: Acesso em: 13.09.2019 07:31

${ }^{53}$ FRIGOTTO, Gaudêncio (org.) Escola “sem” Partido. Rio de Janeiro: LPP/UERJ, 2017. 
${ }^{54} \mathrm{El}$ Pais. PM reprime protesto de professores em Curitiba e mais de 200 se ferem. Disponível em:https://brasil.elpais.com/brasil/2015/04/29/politica/1430337175 476628.html Acesso em: 14/09/2019.

55 No Estado da Bahia, Governo do Partido dos Trabalhadores, o Decreto no 16.417, de 16 de novembro de 2015, que rege sobre contenção de despesas, impôs uma espécie de "ajuste fiscal", o qual vem penalizando os servidores públicos, seja através do congelamento de salários há mais de quatros anos, como também impedindo os professores da educação básica e superior de terem $\mathrm{O}$ direito às licenças para cursos de pós-graduação. Disponível em: https://www.tce.ba.gov.br/images/resposta 88942016 anexo 5.pdf. Acesso em: 14.09.2019(SUGESTÃO: transformar o texto em nota)

${ }^{56}$ FREITAS, H. C. L. Formação de professores no Brasil: 10 anos de embate entre projetos de formação. Educação e Sociedade, Campinas, v. 23, n. 80, p.136-167, 2002. Ver também balanços da ANFOPE. Disponível em: http://www.anfope.org.br/anais/ Acesso em: 13.09.2019 07:31

${ }^{57}$ FRIGOTTO, Gaudêncio. Teoria e educação no labirinto do capital. Rio de Janeiro: Expressão Popular, 2016. EVANGELISTA, João. Crise do marxismo e irracionalismo pós-moderno. São Paulo: Cortez, 1992.

58 EVANGELISTA, João. Crise do marxismo e irracionalismo pós-moderno. São Paulo: Cortez, 1992.

59 A regulamentação da Educação à Distância (EaD) no Brasil ocorreu por meio do Decreto no 5.622 de 19 de dezembro de 2005. Em 2017 o Decreto no 5.622/2005 foi revogado pelo Decreto 9.057 de 25 de maio de 2017. De acordo com o INEP, a partir de 2007, esta modalidade de ensino cresceu significativamente em matrículas no Ensino Superior, conforme dados que indicam que em 2007, estas representavam 7\% das matrículas nos cursos de graduação, passando para 1.756.982 (21,2\%) em 2017. Disponível em: http://portal.mec.gov.br/docman/setembro-2018-pdf/97041-apresentac-a-o-censo-superior-u-ltimo/file. Acesso em: 15.09.2019. Em artigo intitulado "Na Educação, Avanços e Limites", Caldas e Araújo (2017) apontam que a EaD no Brasil teve um aumento de 23.622 matrículas em 2004 para 1.202.469 no final do primeiro mandato do governo Dilma, em 2014. CALDAS, Andrea; ARAÚJO, Luiz. (2014). Na Educação, Avanços e Limites, In. MARINGONI, Gilberto; MEDEIROS, Juliano (orgs.). Cinco mil dias: o Brasil na era do lulismo. 1 ed. São Paulo: Boitempo/Fundação Lauro Campos, 2017. De acordo com a Associação Brasileira de Educação a Distância (ABED), o ano de 2017 registrou 7.773.828 de matrículas em Educação a Distância. Ainda Segundo a Associação, a previsão é que para o ano de 2022, o número de matrículas nesta modalidade já represente 50\% do total de matrículas de ensino superior no país. Ver: Forbes. Educação a distância: um modelo que só cresce. Disponível em: https://forbes.uol.com.br/negocios/2019/03/educacao-a-distancia-um-modelo-que-so-cresce/ Acesso em: 14/09/2019.

60 Programa Instituto e Universidades Empreendedoras e Inovadoras - Future-se. Disponível em: http://estaticog1.globo.com/2019/07/19/programa futurese consultapublica.pdf Acesso em 04.09.2019 23:55.

${ }^{61}$ A Lei No 9.637 de 15 maio de 1998, dispõe sobre a qualificação de entidades como organizações sociais, a criação do Programa Nacional de Publicização, a extinção dos órgãos e entidades que menciona e a absorção de suas atividades por organizações sociais, e dá outras providências. Disponível em: http://www.planalto.gov.br/ccivil 03/leis/19637.htm. Acesso em: 14.09.2019.

62 "A Campanha Nacional de Aperfeiçoamento de Pessoal de Nível Superior (atual CAPES) foi criada em 11 de julho de 1951 (Decreto $n^{\circ}$ 29.741). Seu objetivo foi o de "assegurar a existência de pessoal especializado em quantidade e qualidade suficientes para atender às necessidades dos empreendimentos públicos e privados que visam ao desenvolvimento do país". Disponível em: https://www.capes.gov.br/historia-e-missao. Acesso em 14.09.2019. O Conselho Nacional de Pesquisas (CNPq) foi criado como uma autarquia vinculada à Presidência da República, através da Lei no 1.310 de 15 de Janeiro de 1951, chamada por Álvaro Alberto de "Lei Áurea da pesquisa no Brasil". Disponível em: http://centrodememoria.cnpq.br/Missao2.html. Acesso em 14.09.2019.

${ }_{63}$ Um conjunto abrangente de análises evidenciam a gravidade do projeto. Ver: PCB. UNIDADE CLASSISTA (Frações do ANDES-SN Nacional e SINASEFE). Apontamentos para uma crítica ao projeto Future-se. Disponível em: https://pcb.org.br/portal2/23851/apontamentos-para-uma-critica-ao-projeto-future-se/ Acesso em: 05.09.2019 00:01. CARTA CAPITAL. Future-se: entenda os principais pontos do programa do MEC. Disponível em: https://www.cartacapital.com.br/educacao/future-se-entenda-os-principais-pontos-do-programa-do-mec/ Acesso em: 05.09.2019 00:01. CARTA CAPITAL. Future-se é aposta arriscada baseada em mentiras. Disponível em: https://www.cartacapital.com.br/educacao/future-se-e-aposta-arriscada-baseada-em-mentiras-diz-especialista/ Acesso em: 05.09.2019 00:01. CARTA CAPITAL. MEC quer forçar aprovação do Future-se até quinta-feira. Disponível em: https://www.cartacapital.com.br/educacao/mec-quer-forcar-aprovacao-do-future-se-via-medida-provisoria/ Acesso em: 05.09.2019 00:15. LEHER, Roberto. Análise preliminar do "future-se" indica a refuncionalização das universidades e institutos federais. Disponível em: https://avaliacaoeducacional.files.wordpress.com/2019/07/sobre-o-future-se-notas-prelim-rleher-2407pdf.pdf Acesso em: 05.09.2019 00:17. FILGUEIRAS, Luis. Future-se: a cara de uma elite subalterna. Disponível em: https://outraspalavras.net/crise-brasileira/future-se-a-cara-de-uma-elite-subalterna/ Acesso em: 05.09.2019 00:21. ANDES-SN. Programa Future-se representa a extinção da educação federal pública. Disponível em: https://www.andes.org.br/conteudos/noticia/entidades-do-setor-da-educacao-programa-future-se-representa-a-extincao-daeducacao-federal-publica1 05.09.2019 00:45.

${ }^{64}$ Sobre a intensificação do trabalho docente no ensino superior ver conjunto de estudos relevantes: SGUISSARDI, Valdemar; SILVA JUNIOR, João dos Reis. Trabalho intensificado nas Federais: Pós-Graduação e Produtivismo Acadêmico. 2 ed. Uberlândia: Navegando Publicações, 2018. BOSI, Antônio de Pádua. A precarização do trabalho docente nas instituições de ensino superior do Brasil nesses últimos 25 anos. Educ. Soc., Campinas, vol. 28, n. 101, p. 1503-1523, set./dez. 2007. Disponível em: http://www.scielo.br/pdf/es/v28n101/a1228101 Acesso em 15.09.2019. MANCEBO, Deise; ARAUJO DO VALE, Andréa; BARBOSA MARTINS, Tânia Políticas de expansão da educação superior no Brasil 1995-2010 Revista Brasileira de Educação, vol. 20, núm. 60, enero-marzo, 2015, pp. 31-50 Associação Nacional de Pós-Graduação e Pesquisa em Educação. Rio de Janeiro, Brasil.

65 As perdas salarias acumuladas dos Servidores Públicos Federais - SPF são de monta de 33\%. Recordamos que perdas salariais se referem à perda do poder aquisitivo dos salários frente à inflação. No Brasil, os SPF realizaram recentemente duas grandes greves (2012 e 2015). Nos dois casos, os acordos salariais foram firmados com as categorias isoladamente. No caso dos professores das 
IFE, o PROIFES - associação planejada nos gabinetes dos Ministros de Educação de Lula e criada na sede da CUT-RJ, de representação de base minguada e insignificante em relação ao ANDES-SN, assinou dois acordos nos quais a reposição foi atrelada à reestruturação e quebra da Carreira Docente e parcelada em 4 anos. Sobre a criação do PROIFES ver documento Movimento de Apoio ao ANDES-SN. Disponível em: https://emdefesadoandes.blogspot.com Acesso em: 15.09.2019.

${ }^{66}$ Bancada BBB - bancada armamentista ("da bala"), bancada ruralista ("do boi") e à bancada evangélica (" da bíblia").

67 “[...] visa discutir os impactos da consolidação do Capitalismo como sistema econômico hegemônico mundial no final do século XX nas políticas educacionais dos países periféricos. Para isso, analisou a constituição das organizações financeiras multilaterais e a sua atuação nesses países, tendo como estudo de caso as políticas de financiamento da educação no Brasil. O trabalho buscou apontar como o discurso tecnicista se apresentou de maneira supraclassista e como ele ocultava elementos ideológicos. Concluiuse que as políticas desenvolvidas estavam concatenadas com o ideário proposto pelos organismos financeiros internacionais, repercutindo no alinhamento desses países à tendência econômica e geopolítica hegemônica. Apesar disso, as alternativas e resistências que se apresentaram ao modelo estabelecido no período buscaram superar não somente a proposta de educação sob a lógica do capital, como a própria estrutura capitalista de sociedade".

68 "[...] analisa as definições e orientações do Banco Mundial nas políticas educacionais brasileiras e identifica as novas orientações propostas por esse organismo a partir da imposição de um ajuste considerado "justo" pelo Banco Mundial à educação brasileira. Para tanto, balizamos a revisão de literatura nas evidências de atuação do órgão com as políticas de educação nacionais, dando suporte a análise de dois documentos: "Atingindo uma educação de nível mundial no Brasil: Próximos Passos" e em "Um Ajuste Justo - Análise da Eficiência e Equidade do Gasto Público no Brasil”, no qual o Banco traça, na última parte, as linhas gerais das principais reformas de educação que o país necessita adotar para seguir seu papel periférico na esteira do neoliberalismo, enxugando os gastos do Estado, mediante reformas que abrem caminho à privatização da educação pública”.

69 "[...] As atuais políticas de austeridade adotadas por diversos países capitalistas têm rebatimento direto sobre as condições de vida e trabalho da classe trabalhadora. Tanto nos países centrais como na periferia, a exemplo do Brasil, são colocados na ordem do dia pacotes de ajuste fiscal e reformas estatais que visam retomar a taxa de lucro do capital em queda. Neste sentido, este trabalho trata-se de um estudo bibliográfico que pretende analisar a relação entre a crise capitalista e as políticas de austeridade sobre os trabalhadores no Brasil contemporâneo."

70 "[...] busca demonstrar como o desenvolvimento da crise estrutural do sistema capitalista e suas estratégias, como a criação dos organismos internacionais, os ajustes estruturais e a destruição das forças produtivas através das expropriações e da exploração ampliam o desemprego crônico, ao invés de reduzi-lo, como anunciado."

71 “Objetiva-se, com este ensaio, desenvolver uma análise do processo de tramitação e aprovação da Base Nacional Comum Curricular (BNCC), na medida em que tal Documento sintetiza um dado período histórico e caracteriza-se por ser expressão e símbolo de um Golpe de Estado que redesenhou, via Estado de Exceção, as instituições políticas brasileiras, inclusive, as educacionais. Deve-se destacar que a BNCC representa a objetivação e exteriorização, tanto em sua forma, quanto em seu conteúdo, dos princípios e diretrizes jurídico-políticos, aprovados pela Lei n ${ }^{\circ} 13.415$, de 16 de fevereiro de 2017, e ideologicamente denominada de Reforma do Ensino Médio. Trata-se, portanto, de dois Documentos Institucionais que alteraram profundamente a concepção administrativo-organizativa e pedagógica das instituições político-educacionais. Nesse sentido, buscar-se-á desenvolver uma análise dos Documentos Institucionais, cotejando-os com o processo histórico, a partir do qual emergiram enquanto novo arranjo político-institucional. A hipótese levantada é a de que tanto a BNCC, quanto a chamada Reforma do Ensino Médio, fazem parte da agenda contrarreformista, neoliberal-flexível, imposta de cima para baixo, por um Golpe de Estado no Brasil do século XXI, impondo, pela captura da subjetividade, um colonialismo de novo tipo. Nestes termos, doravante, denominar-se-á o processo em questão, sintetizado em tal Documento, de "A Base do Golpe". Assim, "A Base do Golpe" caracteriza-se por ser uma tentativa de apreensão e entendimento da particularidade histórica brasileira, como forma de construção de um diagnóstico de época, capaz de iluminar o Brasil do século XXI, que em seu segundo decênio passa por uma crise social profunda e aponta para tendências de neocolonialismo, de avanço da barbárie e deterioração das liberdades democráticas."

72 "[...] objetiva explicar os nexos e relações entre a destruição de forças produtivas e o rebaixamento da formação escolar dos filhos da classe trabalhadora. Discute os elementos centrais e as principais contradições do imperialismo e analisa as mudanças fundamentais promovidas pela lei n. 13.415/2017 e a BNCC do ensino médio, apontando os nexos e relações com o processo de destruição de forças produtivas. Foi possível constatar que esses dispositivos acentuam a tendência de esvaziamento científico do currículo escolar e de desqualificação dos jovens trabalhadores ainda no seu processo de escolarização básica. Além disso, integram o movimento de ofensiva do imperialismo no Brasil, de destruição dos serviços públicos e de forças produtivas".

73 “[...] buscou entender como se processa a relação público-privada na educação e de onde vêm essa força do capital que penetra em todas as instâncias do poder público. Esclarecemos que a relação público-privada nada mais é que uma estratégia do capital para criar e ampliar novos nichos de mercado para a superação da crise cíclica do capitalismo, sempre apresentada com novas roupagens nas mutações que se processam, para reduzir os efeitos da inevitável na asfixia social que acabaram por gerar grandes revoluções registrada em seu processo histórico. Por fim, tentou-se demonstrar a influência das relações público-privadas na precarização do trabalho docente e apontar como horizonte a retomada das lutas sociais em defesa da escola pública."

74 “[...] analisa as "competências profissionais" através da discussão de teorias administrativas implantadas na indústria, considerando a divisão do trabalho, a força produtiva e as relações sociais capitalistas. Tais teorias vêm ajustando o trabalhador à nova forma de produção capitalista alicerçada nos "valores organizacionais" e "atitudes aceitáveis". Por consequência, a doutrinação nas empresas consegue reduzir os conflitos e a resistência dos trabalhadores frente à exploração cada vez mais requintada."

75 “[...] aborda o fim da república brasileira para depois caracterizar brevemente a educação para além do capital e sua urgência no atual contexto brasileiro. Analisa também as lutas recentes dos movimentos sociais e sua potencialidade anticapital. Depois disso esboçamos a necessidade de uma teoria da transição ao socialismo adequada à nova fase do capitalismo no país."

76 Visa "situar essa relação entre educação e o trabalho nos diferentes modos de produção, detendo-se a configuração que o modelo assume atualmente, apresentando a necessidade de superação do mesmo para que a educação possa cumprir seu papel, negando as determinações do capital sobre a mesma”. 
77 “[...] tem como objetivo tratar do papel que a escola exerce na formação ideológica das pessoas e da necessidade da construção do sujeito político. Para tal será discutido o posicionamento da escola e a conformação dos meios educacionais, refletindo a partir do movimento das ocupações escolares que ocorrem em 2015 no Brasil, e da Pedagogia Histórico-Crítica, mecanismos e possibilidades que podem contribuir para uma formação revolucionária"

78 “Analisou-se a percepção dos trabalhadores do Sistema Único de Saúde (SUS), em um Curso de Formação Política, acerca dos desafios contemporâneos da saúde pública a luz da matriz marxista. Pedagogicamente, usou-se estratégias ativas emancipadoras e, analiticamente, conduziu-se uma Análise do Conteúdo das percepções dos 86 trabalhadores sobre como o curso contribuiu para compreender estes desafios. Os trabalhadores referiram-se, majoritariamente, ao fato de "Entender(em) melhor a influência do capital na saúde pública". Desta forma, os trabalhadores passaram a delimitar melhor os desafios da saúde pública, diferentemente dos temas que tradicionalmente vem sendo apresentados pela saúde coletiva."

79 "[...] problematiza sobre as comunas camponesas russas e suas possibilidades de transformação, para uma forma superior de organização socialista ou, para sua total desintegração, a partir dos quatro rascunhos de cartas e da resposta enviada de Karl Marx para Vera Zasulitch"

80 “[...] refletir sobre o método de formação política Escola Nacional Florestan Fernandes, uma escola coordenada pelo Movimento dos Trabalhadores Rurais Sem Terra e que tem como principal papel a formação de militantes de movimentos e organizações populares do Brasil e outros países. A ENFF assume a concepção marxista de construção e socialização do conhecimento (MARX, 1987) e a orientação pedagógica da Pedagogia Socialista (PISTRAK, 2009), da Educação Popular (FREIRE, 2005 e da Pedagogia do Movimento (CALDART, 2004). Essa perspectiva pedagógica referencia-se no trabalho como princípio educativo, como práxis que articula a prática com o estudo, em organicidade com a arte e a cultura. A ENFF adota uma perspectiva contra hegemônico, direcionando seu trabalho para a formação da consciência de classe, por meio da socialização de conhecimentos de filosofia, de história e economia de política, considerados necessários para a formação crítica de sujeitos sociais que atuam com vistas à transformação revolucionária da sociedade, superando o capitalismo e avançando em direção ao socialismo, entendendo este como uma fase de transição para o comunismo."

81 “[...] apresentar os benefícios da revolução russa referente ao direito trabalhista, na saúde e na educação, no esporte. Até o século XX na Rússia o trabalhador não tinha nenhum direito trabalhista, mas com a revolução russa o povo conquistou vários benefícios - 8 horas de serviço, férias remuneradas etc. A saúde e a educação passaram a ser gratuitos na Rússia revolucionária. Em 1917 Kotov elaborou uma periodização e depois foram feitas outras pesquisas sobre esse tema onde resultaram em outros modelos. Em conclusão, o socialismo é o meio da sociedade se tornar mais igualitária e com melhor qualidade de vida."

82 “[...] apresentar as divergências gnosiológicas entre Louis Althusser e E. P. Thompson sobre o materialismo histórico concebido por Karl Marx e Friedrich Engels, e tomou como referência as seguintes obras produzidas pelos dois marxistas da segunda metade do século XX: "A favor de Marx" (1965), "Ler o Capital" (1965) e "A miséria da teoria ou um planetário de erros" (1978)"

83 “[...] com o objetivo de elucidar como se estrutura a sociedade capitalista numa perspectiva materialista histórica, buscando esclarecer a transformação da atividade vital do homem, o trabalho, em uma atividade alienada e alienante, caracterizada pela perca de sentido do trabalho que deveria proporcionar a auto realização humano genérica. Diante dessa problemática procuramos apontar o importante papel da educação como ferramenta que pode auxiliar na superação do processo da alienação diante da modernidade capitalista."

84 “[...] trata do trabalho e da educação como base ontológica do homem e seu processo de reprodução social. Partimos do trabalho como princípio da vida humana, que nasce em meio à luta pela existência da vida, mas traz a educação como polo de reprodução social mediado pelo trabalho. O estudo situa trabalho e educação como expressão do homem, que necessita (re)produzir sua vida, pois comer, beber, vestir e morar se conquista no domínio da natureza. Para esse fim, o estudo e análise do objeto trabalho e educação tem como referência autores marxistas, onde buscar-se-á destacar as posições teóricas dos mesmos sobre a base material que funda o ser social, mas aprofundamos o estudo do ser social sob o capitalismo."

85 "Interroga sobre a atitude/reflexão filosóficas e a natureza essencial da educação a fim de chegar aos fundamentos filosóficos da educação caso atenda aos valores sócio-humano genéricos e não à Pedagogia do Capital, alicerçada no irracionalismo pósmoderno"

86 "[...] definir e discutir as categorias teoria, prática e práxis na tradição do materialismo histórico e dialético a partir do filósofo hispano-mexicano Adolfo Sánchez Vázquez e seus desdobramentos para a educação, em especial, para o campo da formação de professores."

87 “[...] visa discutir o papel da Didática e da prática docente na escola básica em uma perspectiva crítica de educação. Inicialmente, discutiremos a Pedagogia como ciência da/para a educação; a Didática em uma perspectiva crítica e o seu papel na formação dos professores. Em seguida, destacaremos a necessidade de práticas docentes pedagógicas que apontem para novos horizontes, novas possibilidades de abordagem do contexto social atual, novos modos de perceber/entender e intervir nessa mesma realidade. Por fim, argumentaremos a favor da articulação entre a Didática, a Pedagogia e as demais áreas das ciências que auxiliam o trabalho docente na escola básica, como um meio de assegurar uma educação inteiramente como chave transformadora da sociedade.”

88 "El trabajo aborda la categoría patrimonio cultural y las implicaciones negativas que le acarrea la posmodernidad en medio de un proceso creciente de globalización. Se realiza un análisis del patrimonio cultural material y espiritual en concomitancia con la autenticidad con una proyección antropológica hacia lo intangible, sin dejar de tener presente la correlación que existe entre ambas vertientes patrimoniales. Se valora lo espiritual o intangible del patrimonio cultural campesino, como parte de la identidad cultural campesina, la cual representa la base fundamental en que se sustenta la identidad nacional, así como se valora el impacto que este tiene en la educación media en Cuba y Brasil y sus efectos contrarios."

89 REDE BRASIL ATUAL. Greve geral: do ensino básico à universidade, educação para contra PEC da Previdência. Disponível em: https://www.redebrasilatual.com.br/trabalho/2019/06/greve-geral-do-ensino-basico-a-universidade-educacao-para-contra-a-reforma-daprevidencia/ Acesso em: 15.09.2019. ANDES-SN. Docentes das Ueba garantem vitórias e encerram greve. Disponível em: https://www.andes.org.br/conteudos/noticia/docentes-das-ueba-garantem-vitorias-e-encerram-greve1. Acesso em: 15.09.2019. REVISTA FORUM. Correios entram em greve nacional contra privatização proposta por Guedes. Disponível 
em: https://revistaforum.com.br/movimentos/correios-entram-em-greve-nacional-contra-privatizacao-proposta-por-guedes/. Acesso em: 15.09.2019. CORREIO BRAZILIENSE ECONOMIA. Contra privatização, Correios decretam greve em todo o país. Disponível em: https://www.correiobraziliense.com.br/app/noticia/economia/2019/09/11/internas economia,781879/contra-privatizacao-correiosdecretam-greve-em-todo-o-pais.shtml. Acesso em 15.09.2019. JORNAL BRASIL DE FATO. 30M: Atos em defesa da educação terminam com chamado à Greve Geral de 14 de junho. Mais de um milhão de pessoas protestaram em 208 cidades contra cortes na Educação e contra reforma da Previdência. Disponível em: https://www.brasildefato.com.br/2019/05/30/30m-atos-em-defesa-da-educacao-terminam-com-chamado-agreve-geral-de-14-de-junho/. Acesso em 15.09.2019. REDE BRASIL ATUAL. Depois do 30 de Maio histórico, movimentos preparam greve geral contra reforma da Previdência. Milhões nas ruas do país, em defesa da educação, fortaleceram a luta contra a reforma da Previdência e a paralisação do dia 14 de junho. Disponível em: https://www.redebrasilatual.com.br/trabalho/2019/05/depois-30-maio-agora-e-greve-geralavisam-lideres-dos-movimentos/. Acesso em: 15.09.2019.

90 FOLHA DE SÃO PAULO. Em 'dia do fogo', sul do PA registra disparo no número de queimadas. Disponível em: https://www1.folha.uol.com.br/ambiente/2019/08/em-dia-do-fogo-sul-do-pa-registra-disparo-no-numero-dequeimadas.shtml Acesso em: 05.09.2019. 12:53. FOLHA DE SÃO PAULO. Investigação do 'dia do fogo' tem dezenas de alvos e celular atirado no rio. Polícia Federal chegou na terça-feira (3) a Novo Progresso para iniciar apuração do caso Disponível em: https://www1.folha.uol.com.br/ambiente/2019/09/investigacao-do-dia-do-fogo-tem-dezenas-de-investigados-e-celularatirado-no-rio.shtml Acesso em: 05.09.2019. 12:53. BBC Brasil. O que se sabe sobre o 'Dia do Fogo', momento-chave das queimadas na Amazônia. Disponível em: https://www.bbc.com/portuguese/brasil-49453037 Acesso em: 05.09.2019. 12:53.

91 JORNAL BRASIL DE FATO. Relatório registra 420 vítimas fatais de discriminação contra LGBTs no Brasil em 2018 . Disponível em: https://www.brasildefato.com.br/2019/02/08/relatorio-registra-420-vitimas-fatais-de-discriminacao-contra-lgbts-no-brasilem-2018/. Acesso em: 15.09.2019. CARTA CAPITAL. 141 pessoas morreram por LGTfobia no Brasil em 2019, diz relatório. Disponível em: https://www.cartacapital.com.br/diversidade/141-pessoas-morreram-por-lgbtfobia-no-brasil-em-2019-dizrelatorio/. Acesso em: 15.09.2019.

92 No dia 29 de julho de 2019 ocorreu uma rebelião entre detentos do Centro de Recuperação Regional de Altamira, no sudoeste do Pará, no qual presos foram degolados. CARTA CAPITAL. Rebelião em presídio deixa 57 mortos no Pará. Disponível em: https://www.cartacapital.com.br/sociedade/rebeliao-em-presidio-deixa-52-mortos-no-para/. Acesso em: 15.09.2019. O GLOBO. Números de mortos em rebelião no Pará sobe para 58. Disponível em: https://oglobo.globo.com/brasil/numero-demortos-em-rebeliao-no-para-sobe-para-58-23844281. Acesso em: 14.09.2019.

93 CEERT. ONG: Brasil é o $4^{\circ}$ país mais perigoso para ativistas do meio ambiente. Disponível em: https://ceert.org.br/noticias/violencia-seguranca/25459/ong-brasil-e-o-4-pais-mais-perigoso-para-ativistas-do-meio-ambiente Acesso em: 15.09.2019. NAÇÕES UNIDAS BRASIL. ONU e CIDH manifestam preocupação com mortes de defensores de direitos humanos nas Américas. Disponível em: https://nacoesunidas.org/onu-e-cidh-manifestam-preocupacao-com-mortes-dedefensores-de-direitos-humanos-nas-americas/. Acesso em: 15.09.2019. EXAME. País tem ao menos 194 mortes de políticos ou ativistas em 5 anos. Disponível em: https://exame.abril.com.br/brasil/pais-tem-ao-menos-194-mortes-de-politicos-ou-ativistasem-5-anos/. Acesso em: 15.09.2019. O GLOBO. Brasil lidera ranking de relatório de ONG com 57 mortes de ativistas ambientais. Disponível em: https://g1.globo.com/natureza/noticia/2018/07/24/brasil-lidera-ranking-de-relatorio-de-ong-com-57-mortesde-ativistas-ambientais.ghtml. Acesso em: 15.09.2019.

94 PETRA COSTA. Documentário Democracia em Vertigem. Disponível em: https://www.netflix.com. Acesso em: 14.09.2019. FOLHA DE SÃO PAULO. New York Times inclui 'Democracia em Vertigem' em lista de melhores do ano. Disponível em: https://www1.folha.uol.com.br/ilustrada/2019/06/new-york-times-inclui-democracia-em-vertigem-em-lista-de-melhoresdo-ano.shtml. Acesso em: 14.09.2019.

95 "Na canga do boi de carro Tem gente amarrado lá, Gente não é boi de carro Pra carro de boi puxar. Gente tem mente que gira Mente que pode girar, gira a mente do carreiro, a canga pode quebrar." Versos de "A canção do carreteiro." Percival. compositor popular de viola e líder rural em Goiás. In Carlos Rodrigues Brandão, "A cultura do povo a prática da classe-canções de militância", Campinas, março de 1980. 